\title{
Carcinoembryonic Antigen as a Predictive Biomarker of Response to Nivolumab in Non-small Cell Lung Cancer
}

\author{
YUKI KATAOKA ${ }^{1}$, KATSUYA HIRANO $^{1}$, TOMOKO NARABAYASHI ${ }^{2}$, SATOSHI HARA ${ }^{3}$, \\ DAICHI FUJIMOTO ${ }^{4}$, TAE TANAKA ${ }^{5}$, NORIYUKI EBI ${ }^{6}$, KEISUKE TOMII ${ }^{4}$ and HIROSHIGE YOSHIOKA ${ }^{7}$ \\ ${ }^{1}$ Department of Respiratory Medicine, Hyogo Prefectural Amagasaki General Medical Center, Amagasaki, Japan; \\ ${ }^{2}$ Department of Internal Medicine, Japan Community Health Care Organization Osaka Hospital, Fukushima, Japan; \\ ${ }^{3}$ Respiratory Division, Department of Internal Medicine, Itami City Hospital, Itami, Japan; \\ ${ }^{4}$ Department of Respiratory Medicine, Kobe City Medical Center General Hospital, Kobe, Japan; \\ ${ }^{5}$ Department of Respiratory Medicine, Kurashiki Central Hospital, Kurashiki, Japan; \\ ${ }^{6}$ Department of Respiratory Medicine, Iizuka Hospital, Iizuka, Japan; \\ ${ }^{7}$ Department of Thoracic Oncology, Kansai Medical University Hospital, Hirakata, Japan
}

\begin{abstract}
Aim: To find new predictive factors for the efficient use of immune checkpoint inhibitors in patients with non-smallcell lung cancer (NSCLC). Patients and Methods: In this multicenter retrospective cohort study, we evaluated consecutive patients treated with nivolumab between January and October 2016 after second-line systemic chemotherapy. The endpoint was progression-free survival (PFS), as defined by Response Evaluation Criteria in Solid Tumors version 1.1. Results: A total of 189 patients were included in the study. Sixty-four percent had received two or more prior systemic therapies. In Cox proportional hazard analyses, Eastern Cooperative Oncology Group Performance Status of 2 or more, lactate dehydrogenase $(\mathrm{LDH}) \geq 217 \mathrm{mg} / \mathrm{dl}$, and carcinoembryonic antigen $\geq 13.8 \mathrm{ng} / \mathrm{ml}$ were independently associated with inferior PFS. LDH was not associated in the sensitivity analysis. Conclusion: In patients with NSCLC treated with nivolumab, worse pretreatment performance status, and higher carcinoembryonic antigen were associated with inferior PFS.
\end{abstract}

Nivolumab has favorable effects on overall survival compared to docetaxel, which has been the standard of care in second-line chemotherapy for advanced non-small cell lung cancer (NSCLC) $(1,2)$. Some patients have shown responses to nivolumab lasting for years (3).

Correspondence to: Yuki Kataoka, MD, MPH, Department of Respiratory Medicine, Hyogo Prefectural Amagasaki General Medical Center, Higashi-Naniwa-Cho 2-17-77, Amagasaki, Hyogo 660-8550, Japan. E-mail: youkiti@gmail.com

Key Words: Nivolumab, non-small cell lung cancer, immunotherapy, carcinoembryonic antigen.
Although immune checkpoint inhibitors (ICIs) such as nivolumab have a clear efficacy, they are associated with high cost (3). Programmed cell death-ligand 1 (PD-L1) is a promising biomarker which can be used to select patients who could benefit from ICI therapies (4). However, administration of ICIs for selected patients using PD-L1 as a biomarker is not cost effective even in developed countries $(3,5)$.

Several factors such as the mutation burden, lactate dehydrogenase (LDH) level, performance status (PS), and neutrophil/lymphocyte ratio (NLR) have been explored to predict the efficacy of ICIs. However, all of them have limited predictive value (6-9).

Hence, we evaluated the predictive values of pretreatment serum markers in patients previously treated with nivolumab for advanced NSCLC in usual clinical settings.

\section{Patients and Methods}

Study design and patients. We followed the Strengthening the Reporting of Observational Studies in Epidemiology (STROBE) Statement during all stages of design, implementation, and reporting (10).

A retrospective cohort study was performed. The cohort included patients with pathologically proven NSCLC (11) who had received nivolumab ( $3 \mathrm{mg} / \mathrm{kg}$ intravenously every 2 weeks) as second-line or later treatment between January and November 2016 at five tertiary hospitals in Japan. December 2015 was the date of approval of nivolumab in Japan. Those who received nivolumab as part of a clinical trial were excluded from our cohort. The end date for the observation period for this study was December 2016.

Definitions of prognostic variables. Data on demographics including age, sex, comorbidity, number of prior systemic chemotherapy, histological type, PS, smoking history, and each of the serum markers [NLR, LDH, carcinoembryonic antigen (CEA), and 


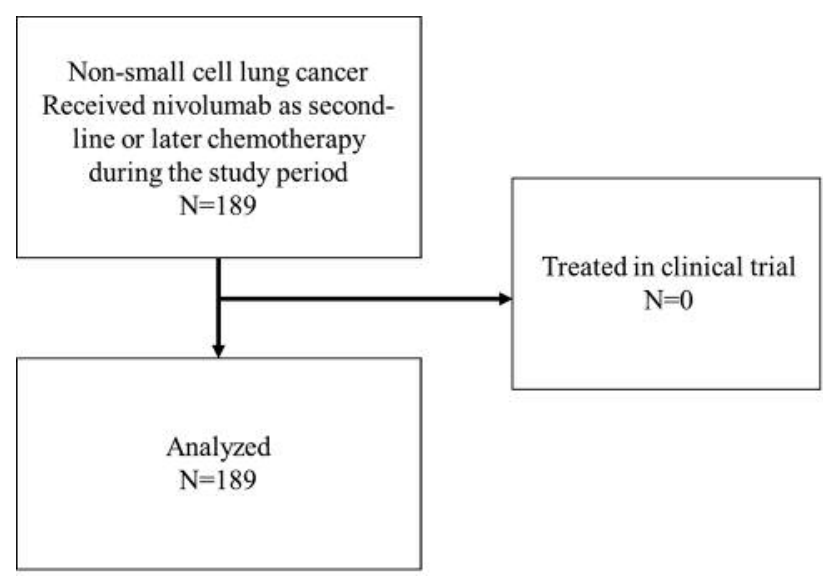

Figure 1. Study flow chart.

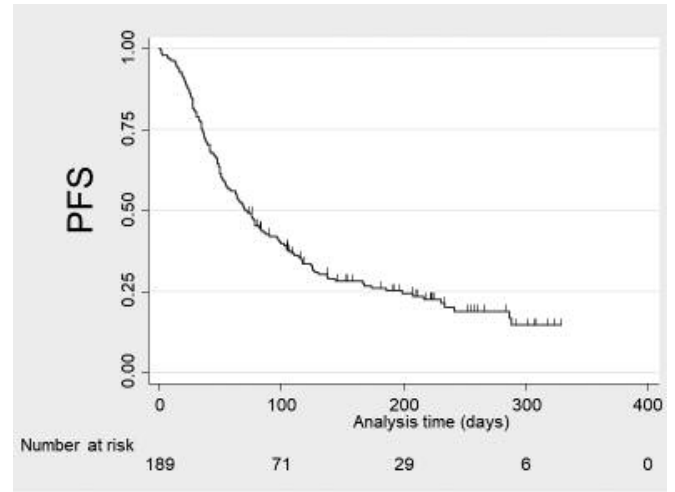

Figure 2. Kaplan-Meier survival curve for progression-free survival (PFS) of patients treated with nivolumab for non-small cell lung cancer. fragments of cytokeratin-19 (CYFRA)] at the time of first administration of nivolumab were extracted from the chart review. CEA and CYFRA were measured by chemiluminescent enzyme immunoassay. Epidermal growth factor receptor $(E G F R)$, and anaplastic lymphoma kinase $(A L K)$ status were available only if such profiling had been performed as part of the routine clinical care. We defined cut-offs based on previous studies or median values $(8,9,12,13)$

Definition of study endpoint. Progression-free survival (PFS) as defined by Response Evaluation Criteria In Solid Tumors (RECIST) version 1.1 (14) was used as the endpoint. We chose this endpoint because the treatment line for each patient was very different, and the observation period was limited. At each hospital, computed tomographic (CT) scans were performed every 6 to 8 weeks in routine care. Two researchers evaluated the endpoints independently and any disagreements were resolved by discussion.

Statistical analyses. Background information was summarized using summary statistics. PFS was estimated using the KaplanMeier method. Cox proportional hazards models were used to assess the impact of pretreatment markers on PFS. We used multiple imputations to handle missing data assuming they were randomly missing. Twenty datasets were imputed by normal regression and estimates from these datasets were combined using Rubin's rule (15). We conducted a sensitivity analysis of the complete-case data set. We used Stata ${ }^{\circledR}$ ver. 13.1 (Stata Corp., College Station, TX, USA).

Ethical considerations. This study was performed according to the Declaration of Helsinki and the Ethical Guidelines for Medical and Health Research Involving Human Subjects from the Japanese Ministry of Health, Labour and Welfare. The protocol for the study was approved by the Ethics Committee of each hospital and requirement for informed consent was waived. The protocol was registered in the University Hospital Medical Information Network Clinical Trials Registry with the number: UMIN000022014.

\section{Results}

Characteristics. We included 189 patients with advanced NSCLC treated with nivolumab. No patients were excluded (Figure 1). Baseline characteristics are summarized in Table I. The median age of the patients was 69 (range=38-88) years; $26 \%$ were women, and $64 \%$ had received two or more prior systemic therapies. They received a median of five cycles (interquartile range $=3-8$ ) of nivolumab treatment.

Survival analyses. The median follow-up time was 5.5 months. Forty-six (24\%) patients were censored. The median progression-free time was 2.4 months (Figure 2). Both univariate and multivariate analyses showed that PS of 2 or more, $\mathrm{LDH} \geq 217 \mathrm{mg} / \mathrm{dl}$, and CEA $\geq 13.8 \mathrm{ng} / \mathrm{ml}$ were associated with decreased PFS (Table II). In the sensitivity analysis performed via complete-case multivariate analysis, PS of 2 or more, presence of targetable driver mutation, and CEA $\geq 13.8$ $\mathrm{ng} / \mathrm{ml}$ were associated with decreased PFS (Table III).

\section{Discussion}

Our findings reveal that a high serum level of CEA and a poor PS were associated with a decreased PFS in patients with advanced NSCLC previously treated with nivolumab. Some previous studies have also shown the association between a high serum level of CEA and poor prognosis in patients with advanced NSCLC $(16,17)$. To the best of our knowledge, this is the first report of a serum tumor marker predicting the effectiveness of ICIs in patients with advanced NSCLC.

Squamous cell histology ( $v s$. non-squamous histology) is reported as a predictive factor for ICIs (18). In this study, we analyzed tumor markers and histology simultaneously. High 
CEA was associated with decreased PFS, but squamous cell histology was not. This discrepancy suggests a predictive role for CEA which reflects the proportion of the histological subtype (19).

High serum LDH was associated with decreased PFS in the main analysis, but not in the sensitivity analysis. We used multiple imputations because the missing values were thought to be lost at random. Multiple imputations have been recommended for handling missing data (20). It is also reported to reduce bias from missing data and improve the precision of estimates (20). LDH has been reported as a predictive marker in patients with NSCLC treated with pembrolizumab (18). However, the predictive value of serum LDH needs further investigation.

In contrast, targetable driver gene mutations, smoking history, and NLR were not predictive factors. One reason could be the difference in the target population from those of previous studies. In this study, more than half of the patients had received three prior systemic chemotherapies, while prior studies that reported the predictive value of these factors included patients who had received fewer than two prior systemic chemotherapies $(8,21)$. Heavily treated cancer is known to accumulate mutations (22), which is an important predictive factor for response to ICIs (23) and could have acted as an unmeasured confounding factor.

Our study had several limitations. Firstly, the expression of PD-L1 in tumor tissues was not evaluated, although nivolumab was reported to have significant efficacy in a subset of patients with PD-L1-negative patients with NSCLC (2). Moreover, the expression of PD-L1 can change during chemotherapy $(24,25)$. Because PD-L1 expression with treatment is likely to be different from that at the time of diagnosis, the evaluation of serum markers which can easily be made during the course of treatment is important. Secondly, the timing of the CT scans was not predefined due to the retrospective nature of the study. At each hospital, CT scans were taken every 6 to 8 weeks in routine care. Finally, even with the careful use of the RECIST criteria, misclassification can occur (26). We believe that the evaluation by two independent observers would have reduced the information bias in this study.

In conclusion, CEA is a predictive marker of PFS in patients with advanced NSCLC treated with nivolumab. Patients with high CEA and worse PS should not be treated with nivolumab. A larger study with fewer missing values is needed to verify the reproducibility of our present findings.

\section{Funding Sources}

This work was supported in part by a grant from the Hyogo Prefectural Amagasaki General Medical Center's fiduciary funds (for English editing).
Table I. Patient characteristics $(n=189)$

\begin{tabular}{|c|c|c|}
\hline Characteristic & $\begin{array}{c}\text { Complete set } \\
\mathrm{N}(\%)\end{array}$ & $\begin{array}{c}\text { Imputed set } \\
\mathrm{N}(\%)\end{array}$ \\
\hline \multicolumn{3}{|l|}{ Age } \\
\hline$<75$ Years & $140(74)$ & \\
\hline$\geq 75$ Years & $49(26)$ & \\
\hline \multicolumn{3}{|l|}{ Gender } \\
\hline Female & $50(26)$ & \\
\hline Male & $139(74)$ & \\
\hline \multicolumn{3}{|l|}{ Comorbidity } \\
\hline Autoimmune disease & $3(2)$ & \\
\hline Interstitial lung disease & $10(5)$ & \\
\hline \multicolumn{3}{|c|}{ No. of prior systemic chemotherapies } \\
\hline 1 & $14(7)$ & \\
\hline 2 & $32(17)$ & \\
\hline$\geq 3$ & $143(76)$ & \\
\hline \multicolumn{3}{|l|}{$A L K$} \\
\hline Negative & $143(75)$ & $185(98)$ \\
\hline Positive & $3(2)$ & $4(2)$ \\
\hline Missing data & $43(23)$ & \\
\hline \multicolumn{3}{|l|}{$E G F R$} \\
\hline Negative & $138(73)$ & $158(84)$ \\
\hline Positive & $27(14)$ & $31(16)$ \\
\hline Missing data & $24(13)$ & \\
\hline \multicolumn{3}{|l|}{ Histology } \\
\hline Squamous & $46(24)$ & \\
\hline Non-squamous & $143(76)$ & \\
\hline ECOG PS & 0 & $32(17)$ \\
\hline 1 & $117(62)$ & \\
\hline 2 & $34(18)$ & \\
\hline 3 & $5(3)$ & \\
\hline 4 & $1(1)$ & \\
\hline RECIST response & $\mathrm{CR}$ & $2(1)$ \\
\hline PR & $32(17)$ & \\
\hline $\mathrm{SD}$ or non $\mathrm{CR} /$ non $\mathrm{PD}$ & $54(28)$ & \\
\hline PD & $88(47)$ & \\
\hline $\mathrm{NE}$ & $13(7)$ & \\
\hline \multicolumn{3}{|l|}{ Smoking status } \\
\hline Current or ex-smoker & $147(78)$ & \\
\hline Never & $42(22)$ & \\
\hline \multicolumn{3}{|c|}{ Neutrophil-to-lymphocyte ratio } \\
\hline$<5$ & $130(69)$ & \\
\hline$\geq 5$ & $59(31)$ & \\
\hline \multicolumn{3}{|l|}{ LDH (mg/dl) } \\
\hline$<217$ & $90(48)$ & \\
\hline$\geq 217$ & $99(52)$ & \\
\hline \multicolumn{3}{|l|}{ CEA (ng/ml) } \\
\hline$<13.8$ & $76(40)$ & $91(48)$ \\
\hline$\geq 13.8$ & $78(41)$ & $98(51)$ \\
\hline Missing data & $35(19)$ & \\
\hline \multicolumn{3}{|l|}{ CYFRA (ng/ml) } \\
\hline$<5.05$ & $65(34)$ & $88(47)$ \\
\hline$\geq 5.05$ & $69(37)$ & $101(53)$ \\
\hline Missing data & $55(29)$ & \\
\hline
\end{tabular}

ALK, Anaplastic lymphoma kinase; EGFR, epidermal growth factor receptor; ECOG PS, Eastern Cooperative Oncology Group Performance Status; RECIST, response evaluation criteria in solid tumors; CR, complete response; PR, partial response; SD, stable disease; PD, progressive disease; NE, not evaluable; $\mathrm{LDH}$, lactate dehydrogenase; CEA, carcinoembryonic antigen; CYFRA, fragments of cytokeratin-19. 
Table II. Unadjusted and adjusted hazard ratio for progression-free survival of patients treated with nivolumab for non-small cell lung cancer.

\begin{tabular}{|c|c|c|c|c|c|}
\hline Factor & Comparison & $\begin{array}{l}\text { Unadjusted hazard } \\
\text { ratio }(95 \% \mathrm{CI})\end{array}$ & $p$-Value & $\begin{array}{c}\text { Adjusted hazard ratio } \\
(95 \% \mathrm{CI})\end{array}$ & $p$-Value \\
\hline Histology & Non Sq vs. Sq & $0.72(0.48$ to 1.08$)$ & 0.11 & $0.91(0.59$ to 1.42$)$ & 0.68 \\
\hline ECOG PS & $0,1 v s . \geq 2$ & $2.00(1.34-2.98)$ & 0.001 & $1.94(1.29-2.92)$ & 0.003 \\
\hline Smoking status & Current $v s$. light or never & $0.87(0.59-1.27)$ & 0.47 & $1.13(0.71-1.80)$ & 0.61 \\
\hline Targetable driver mutation & Absent $v s$. present & $1.48(0.96-2.27)$ & 0.07 & $1.67(0.98-2.84)$ & 0.06 \\
\hline NLR & $\geq 5 v s .<5$ & $1.12(0.79-1.60)$ & 0.52 & $1.00(0.99-1.01)$ & 0.57 \\
\hline LDH & $\geq 217 v s .<217 \mathrm{mg} / \mathrm{dl}$ & $1.60(1.15-2.23)$ & 0.004 & $1.60(1.12-2.30)$ & 0.007 \\
\hline CEA & $\geq 13.8 v s .<13.8 \mathrm{ng} / \mathrm{ml}$ & $2.02(1.40-2.90)$ & 0.002 & $1.72(1.17-2.53)$ & 0.005 \\
\hline CYFRA & $\geq 5.05 v s .<5.05 \mathrm{ng} / \mathrm{ml}$ & $1.29(0.87-1.92)$ & 0.17 & $1.19(0.82-1.73)$ & 0.36 \\
\hline
\end{tabular}

CEA: Carcinoembryonic antigen, CI: confidence interval, CYFRA 21-1: fragments of cytokeratin-19, ECOG PS: Eastern Cooperative Oncology Group Performance Status, LD: lactate dehydrogenase, NLR: neutrophil-to-lymphocyte ratio, Sq: squamous cell carcinoma.

Table III. Unadjusted and adjusted hazard ratio for progression free survival (complete-case analysis)

\begin{tabular}{|c|c|c|c|c|c|}
\hline Factor & Comparison & $\begin{array}{l}\text { Unadjusted hazard } \\
\text { ratio }(95 \% \mathrm{CI})\end{array}$ & $p$-Value & $\begin{array}{l}\text { Adjusted hazard ratio } \\
\quad(95 \% \mathrm{CI})(\mathrm{n}=91)\end{array}$ & $p$-Value \\
\hline Histology & Non $\mathrm{Sq} v s . \mathrm{Sq}(\mathrm{n}=189)$ & $0.72(0.48-1.08)$ & 0.11 & $1.38(0.55-3.53)$ & 0.49 \\
\hline ECOG PS & $0,1 v s . \geq 2(\mathrm{n}=189)$ & $2.00(1.34-2.98)$ & 0.001 & $2.30(1.22-4.34)$ & 0.01 \\
\hline Smoking status & Current $v s$. light or never $(\mathrm{n}=189)$ & $0.87(0.59-1.27)$ & 0.47 & $0.93(0.50-1.72)$ & 0.81 \\
\hline Targetable driver mutation & Absent vs. present $(\mathrm{n}=149)$ & $1.35(0.87-2.10)$ & 0.18 & $2.14(1.11-4.14)$ & 0.02 \\
\hline NLR & $\geq 5$ vs. $<5(\mathrm{n}=189)$ & $1.12(0.79-1.60)$ & 0.52 & $1.18(0.62-2.23)$ & 0.62 \\
\hline LDH & $\geq 217 v s .<217 \mathrm{mg} / \mathrm{dl}(\mathrm{n}=189)$ & $1.63(1.17-2.26)$ & 0.004 & $1.19(0.68-2.08)$ & 0.55 \\
\hline CEA & $\geq 13.8 v s .<13.8 \mathrm{ng} / \mathrm{ml}(\mathrm{n}=154)$ & $2.02(1.40-2.90)$ & $<0.001$ & $1.87(1.10-3.18)$ & 0.02 \\
\hline CYFRA & $\geq 5.05 v s .<5.05 \mathrm{ng} / \mathrm{ml}(\mathrm{n}=134)$ & $1.26(0.85-1.87)$ & 0.25 & $1.06(0.62-1.80)$ & 0.83 \\
\hline
\end{tabular}

CEA: Carcinoembryonic antigen, CI: confidence interval, CYFRA 21-1: fragments of cytokeratin-19, ECOG PS: Eastern Cooperative Oncology Group Performance Status, LD: lactate dehydrogenase, NLR: neutrophil-to-lymphocyte ratio, Sq: squamous cell carcinoma.

\section{Conflicts of Interest}

D. Fujimoto and K. Hirano received honoraria from Ono Pharmaceutical Company and Bristol-Myers Squibb. K. Tomii received honoraria from Boehringer Ingelheim. H. Yoshioka received honoraria from Eli Lilly, Chugai Pharma, Boehringer Ingelheim, Taiho Pharmaceutical, Pfizer, AstraZeneca, Bristo-Myers Squibb, Ono Pharmaceutical, and Takeda.

\section{Acknowledgements}

The Authors thank Ms. Michie Kashiwabara and Ms. Misayo Ata for helping with the chart review, and Dr. Akira Hagiwara for interpreting the computed tomography data.

\section{References}

1 Brahmer J, Reckamp KL, Baas P, Crinò L, Eberhardt WEE, Poddubskaya E, Antonia S, Pluzanski A, Vokes EE, Holgado E, Waterhouse D, Ready N, Gainor J, Arén Frontera O, Havel L, Steins M, Garassino MC, Aerts JG, Domine M, Paz-Ares L,
Reck M, Baudelet C, Harbison CT, Lestini B and Spigel DR: Nivolumab versus docetaxel in advanced squamous-cell nonsmall-cell lung cancer. N Engl J Med 373: 123-135, 2015.

2 Borghaei H, Paz-Ares L, Horn L, Spigel DR, Steins M, Ready NE, Chow LQ, Vokes EE, Felip E, Holgado E, Barlesi F, Kohlhäufl M, Arrieta $\mathrm{O}$, Burgio MA, Fayette J, Lena H, Poddubskaya E, Gerber DE, Gettinger SN, Rudin CM, Rizvi N, Crinò L, Blumenschein GR, Antonia SJ, Dorange C, Harbison $\mathrm{CT}$, Graf Finckenstein $\mathrm{F}$ and Brahmer JR: Nivolumab versus docetaxel in advanced nonsquamous non-small-cell lung cancer. N Engl J Med 373: 1627-1639, 2015.

3 Matter-Walstra K, Schwenkglenks M, Aebi S, Dedes K, Diebold J, Pietrini M, Klingbiel D, von Moos R and Gautschi O: A costeffectiveness analysis of nivolumab versus docetaxel for advanced nonsquamous NSCLC including PD-L1 testing. J Thorac Oncol 11: 1846-1855, 2016.

4 Khunger M, Hernandez AV, Pasupuleti V, Rakshit S, Pennell NA, Stevenson J, Mukhopadhyay S, Schalper K and Velcheti V: Programmed cell death 1 (PD-1) Ligand (PD-L1) expression in solid tumors as a predictive biomarker of benefit from PD-1/PDL1 axis inhibitors: a systematic review and meta-analysis. JCO Precis Oncol 1: 1-15, 2017. 
5 Kohn CG, Zeichner SB, Chen Q, Montero AJ, Goldstein DA and Flowers CR: Cost-effectiveness of immune checkpoint inhibition in BRAF wild-type advanced melanoma. J Clin Oncol 35: 11941202, 2017.

6 Rizvi NA, Hellmann MD, Snyder A, Kvistborg P, Makarov V, Havel JJ, Lee W, Yuan J, Wong P, Ho TS, Miller ML, Rekhtman N, Moreira AL, Ibrahim F, Bruggeman C, Gasmi B, Zappasodi R, Maeda Y, Sander C, Garon EB, Merghoub T, Wolchok JD, Schumacher TN and Chan TA: Cancer immunology. Mutational landscape determines sensitivity to PD-1 blockade in non-small cell lung cancer. Science 348: 124-128, 2015.

7 Sundar R, Cho B-C, Brahmer JR and Soo RA: Nivolumab in NSCLC: latest evidence and clinical potential. Ther Adv Med Oncol 7: 85-96, 2015.

8 Bagley SJ, Kothari S, Aggarwal C, Bauml JM, Alley EW, Evans TL, Kosteva JA, Ciunci CA, Gabriel PE, Thompson JC, Stonehouse-Lee S, Sherry VE, Gilbert E, Eaby-Sandy B, Mutale F, DiLullo G, Cohen RB, Vachani A and Langer CJ: Pretreatment neutrophil-to-lymphocyte ratio as a marker of outcomes in nivolumab-treated patients with advanced nonsmall-cell lung cancer. Lung Cancer 106: 1-7, 2017.

9 Kanai O, Fujita K, Okamura M, Nakatani K and Mio T: Severe exacerbation or manifestation of primary disease related to nivolumab in non-small-cell lung cancer patients with poor performance status or brain metastases. Ann Oncol 27: 13541356, 2016.

10 Vandenbroucke JP, von Elm E, Altman DG, Gøtzsche PC, Mulrow CD, Pocock SJ, Poole C, Schlesselman JJ, Egger M and STROBE initiative: Strengthening the Reporting of Observational Studies in Epidemiology (STROBE): explanation and elaboration. Ann Intern Med 147: W163-94, 2007.

11 International Association for the Study: IASLC Staging Handbook in Thoracic Oncology. 1st ed. Orange Park, FL, EditorialRx Press, 2009.

12 Diem S, Kasenda B, Spain L, Martin-Liberal J, Marconcini R, Gore $\mathrm{M}$ and Larkin J: Serum lactate dehydrogenase as an early marker for outcome in patients treated with anti-PD-1 therapy in metastatic melanoma. Br J Cancer 114: 256-261, 2016.

13 Taniguchi Y, Tamiya A, Isa S, Nakahama K, Okishio K, Shiroyama T, Suzuki H and Inoue T: Predictive factors for poor progression-free survival in patients with non-small cell lung cancer treated with nivolumab. Anticancer Res 37: 5857-5862, 2017.

14 Eisenhauer EA, Therasse P, Bogaerts J, Schwartz LH, Sargent D, Ford R, Dancey J, Arbuck S, Gwyther S, Mooney M, Rubinstein L, Shankar L, Dodd L, Kaplan R, Lacombe D and Verweij J: New response evaluation criteria in solid tumours: revised RECIST guideline (version 1.1). Eur J Cancer 45: 228-247, 2009.

15 Rubin DB: Multiple Imputation for Nonresponse in Surveys. (Rubin DB (ed.)). Hoboken, NJ, USA, John Wiley \& Sons, Inc., 1987.

16 Ardizzoni A, Cafferata MA, Tiseo M, Filiberti R, Marroni P, Grossi F and Paganuzzi M: Decline in serum carcinoembryonic antigen and cytokeratin 19 fragment during chemotherapy predicts objective response and survival in patients with advanced nonsmall cell lung cancer. Cancer 107: 2842-2849, 2006.
17 Arrieta O, Villarreal-Garza C, Martínez-Barrera L, Morales M, Dorantes-Gallareta Y, Peña-Curiel O, Contreras-Reyes S, Macedo-Pérez EO and Alatorre-Alexander J: Usefulness of serum carcinoembryonic antigen (CEA) in evaluating response to chemotherapy in patients with advanced non small-cell lung cancer: a prospective cohort study. BMC Cancer 13: 254, 2013.

18 Herbst RS, Baas P, Kim D-W, Felip E, Perez-Gracia JL, Han J$\mathrm{Y}$ and Molina JR: Factors associated with better overall survival (OS) in patients with previously treated, PD-L1-expressing, advanced NSCLC: multivariate analysis of KEYNOTE-010. In: ASCO Annual Meeting. p. 9090, 2017.

19 Grunnet M and Sorensen JB: Carcinoembryonic antigen (CEA) as tumor marker in lung cancer. Lung Cancer 76: 138-143, 2012.

20 Little RJ, D’Agostino R, Cohen ML, Dickersin K, Emerson SS, Farrar JT, Frangakis C, Hogan JW, Molenberghs G, Murphy SA, Neaton JD, Rotnitzky A, Scharfstein D, Shih WJ, Siegel JP and Stern $\mathrm{H}$ : The Prevention and treatment of missing data in clinical trials. N Engl J Med 367: 1355-1360, 2012.

21 Diem S, Schmid S, Krapf M, Flatz L, Born D, Jochum W, Templeton AJ and Früh M: Neutrophil-to-lymphocyte ratio (NLR) and platelet-to-lymphocyte ratio (PLR) as prognostic markers in patients with non-small cell lung cancer (NSCLC) treated with nivolumab. Lung Cancer 111: 176-181, 2017.

22 Mouw KW, Goldberg MS, Konstantinopoulos PA and D' Andrea $\mathrm{AD}$ : DNA damage and repair biomarkers of immunotherapy response. Cancer Discov 7: 675-693, 2017.

23 Rizvi NA, Hellmann MD, Snyder A, Kvistborg P, Makarov V, Havel JJ, Lee W, Yuan J, Wong P, Ho TS, Miller ML, Rekhtman N, Moreira AL, Ibrahim F, Bruggeman C, Gasmi B, Zappasodi R, Maeda Y, Sander C, Garon EB, Merghoub T, Wolchok JD, Schumacher TN and Chan TA: Mutational landscape determines sensitivity to PD-1 blockade in non-small cell lung cancer. Science 348: 124-128, 2015.

24 Omori S, Kenmotsu H, Masato A, Watanabe R, Sugino T and Wakuda K: Changes in PD-L1 expression in non-small cell lung cancer by immunohistochemical analysis. J Clin Oncol 33: e22118, 2015.

25 Han JJ, Kim D-W, Koh J, Keam B, Kim TM, Jeon YK, Lee S$\mathrm{H}$, Chung DH and Heo DS: Change in PD-L1 expression after acquiring resistance to gefitinib in EGFR-mutant non-small-cell lung cancer. Clin Lung Cancer 17: 263-270.e2, 2016.

26 Muenzel D, Engels H-P, Bruegel M, Kehl V, Rummeny E and Metz S: Intra- and inter-observer variability in measurement of target lesions: implication on response evaluation according to RECIST 1.1. Radiol Oncol 46: 8-18, 2012.
Received October 24, 2017

Revised November 9, 2017 Accepted November 10, 2017 